\title{
EFFECTS OF PLANTING DATES ON GROWTH, YIELD AND QUALITY OF NEWLY RELEASED SUGARCANE VARIETIES
}

\author{
M.A.T. Sohel*, M.S. Hossain, N. Islam, M. Kamruzaman, F.H. Shantaand R.R. Rajib \\ Bangladesh Sugarcrop Research Institute, Ishurdi, Pabna, Bangladesh \\ Corresponding E-mail: atsohel@yahoo.com
}

(Received: 31July 2021, Accepted: 16September 2021)

Key words: Sugarcane, planting date, yield

\begin{abstract}
The experiment was conducted at farmer's field of Kapasia, Gazipur during November, 2011 to March, 2013under the AEZ 28 (Modhupur Tract).The experiment was carried out to find the effects of varieties and planting dates on growth, yield and quality of sugarcane. Two varieties (viz; Isd 38 and Isd 39) and five planting datesfrommid-November to mid-Marchwere laid out in a Factorial Randomized Complete Block (RCB) design with three replications. Among the varieties, there was no significant difference; however Isd 38 performed better than Isd 39 in all aspect of yield contributing characters. Growth characters viz., tillers and millable cane stalks were significantly influenced by different planting dates. The highest germination $(72.17 \%)$, tiller $\left(111.03 \times 10^{3} \mathrm{ha}^{-1}\right)$, millable cane $\left(91.12 \times 10^{3}\right.$ $\left.\mathrm{ha}^{-1}\right)$, pol \% cane $(14.91 \%)$ and cane yield $\left(75.47 \mathrm{t} \mathrm{ha}^{-1}\right)$ were obtained from midNovember planting and gradually decreased with the advancement of planting times where all the lowest values were recorded from mid-March planting. Interaction between variety and planting date, mid-November planting with Isd 38 produced the highest germination $(73.67 \%)$, tiller $\left(115.39 \times 10^{3} \mathrm{ha}^{-1}\right)$, millable cane $\left(98.16 \times 10^{3}\right.$ $\left.\mathrm{ha}^{-1}\right)$, pol \% cane $(14.95 \%)$ and cane yield $\left(93.64 \mathrm{t} \mathrm{ha}^{-1}\right)$. The overall results revealed that variety Isd 38 in mid-November planting is optimum for sugarcane production under the Modhupur tract soils of Bangladesh.
\end{abstract}

\section{Introduction}

The total area and production of sugarcane in Bangladesh are gradually reducing. At present, the area under sugarcane is about 80.97 thousand hectares covering both mill and non-mill zones with an annual production of about 3142 thousand tons (BBS, 2019). Although BSRI released high recovery (11-12 $\%$ ) varieties but in the mills it stands at $6.51-8.4 \%$ and for last few years it is almost to $7.0 \%$ (Alam et al., 2009).

There are number of reasons for lower cane yield and one of those is the planting of low yielding varieties. Therefore, it is need of the time to introduce new high yielding varieties with good ratoon ability in the country (Chattha and Ehsanullah, 2003). Mian (2006) reported that variety plays a key role in both increasing and decreasing per unit area sugar yield. The use of inferior quality cane varieties affect sugarcane production negatively as situation prevails today. The solution of low cane yield and sugar recovery problem lies in the planting time of improved cane varieties (Chattha et al., 2006).Selection of a proper variety to be grown in a particular agro-ecological zone is a primary requisite to explore its yield and sugar recovery potential(James, 2004).

Viator et al., (2005) stated that planting date is one of the important variables that affects sugarcane stand establishment. Hoy et al., (2006) observed that cane weight and maturity of sugarcane are highly associated with planting time that may influence its productivity. Due to late planting, the cane 
germination and tiller population become lowered consequently resulted in lesser millable cane stalk production and hence reduced final cane yield (Omoto and Abaya, 2005). Hossain et al. (2011) concluded that growth characters like tillers, millable cane stalks, cane height, girth and unit stalk weight were significantly influenced by different planting dates. The values of all the yield contributing factors and quality parameters were higher in the crops planted in November compared to that planted in February and March. Early and late planting had resulted in reduced yield of sugarcane (Hoy et al., 2006). A progressive decrease in sucrose content of cane juice was recorded with delay in each planting date. Munsif et al. (2018) also observed that higher number of tillers, millable cane production, cane yield and higher sugar recovery was achieved from early planting. Jintrawet et al., (2000) found that sugarcane planted during the first week of November gave higher cane yield. The present study was conducted with aim to compare the latest varieties each other and to find out the appropriate planting date for higher yield of sugarcane under the Modhupur tract soils of Gazipur region.

\section{Materials and Methods}

The experiment was conducted at grower's field in Kapasia, Gazipur during November, 2011 to March, 2013 under the AEZ 28. The experiment was laid out in a Factorial Randomized Complete Block (RCB) design with three replications. Each experimental plot had a size of $36.0 \mathrm{~m}^{2}$. The treatments were included in the experiment such as factor $\mathrm{A}$ : Two varieties $\mathrm{V}_{1}$ : Isd 38 and $\mathrm{V}_{2}$ : Isd 39 whereas factor $\mathrm{B}$ : Five planting dates as $\mathrm{P}_{1}$ : Mid November, 2011, $\mathrm{P}_{2}$ : Mid December, 2011, $\mathrm{P}_{3}$ : Mid-January, 2012, $\mathrm{P}_{4}$ : Mid February, 2012 and $\mathrm{P}_{5}$ : Mid-March, 2012.. Trenches were made by hand spade. Setts containing two buds were planted end to end in the main field on 15th of the said months maintaining $100 \mathrm{~cm}$ row distance. Application of fertilizers was given @ 260, 152, 250, 139 and $6 \mathrm{~kg}$ ha-1 as Urea, TSP, MP, Gypsum and Zinc Sulphate, respectively (FRG, BARC, 2005). Full doses of TSP, Gypsum, Zinc Sulphate, 1/3rd of Urea and MP; Regent 3GR @ $22 \mathrm{~kg} \mathrm{ha}^{-1}$ for control termite were applied in trenches during the time of plantation. The rest of MP and Urea were applied in two equal splits at early tillering stage and late tillering phase of sugarcane. Necessary intercultural operations like weeding, mulching, irrigation and pest management were done as and when required. Furadan $5 \mathrm{G}$ was applied as a preventive measure against borers in two times at 90 and 150 DAP @ $40 \mathrm{~kg} \mathrm{ha}^{-1}$ for each time. Disregarding of the planting dates, all cane were harvested at maturity stage. During the course of the experiment germination, tiller and millable cane production were taken. Moreover yield of cane and Pol \% cane were measured at harvest. Economic and statistical analyses on different parameters were done following the standard procedures. The treatment means that were significantly different at $5 \%$ levels of significance were separated using the Duncan Multiple Rang Test (DMRT).

\section{Results and Discussion}

\section{Germination percentage}

\section{Effects of variety}

Germination percentage was not significant response by varieties (Table 1). The variety Isd 38 produced the numerically maximum $(59.40 \%)$ germination percentage than the variety Isd 39 (57.67\%). Thus, in the present finding the variation in germination percentage could be probably attributed to the differences in the genetic makeup of the varieties (Worku and Chinawong, 2006).

\section{Effects of planting date}

Planting date exerted a significant effect on germination percentage (Table 1). The results indicate that the highest germination percentage $(72.17 \%$ ) was measured from mid-November planting whereas, the lowest germination percentage $(52.50 \%)$ from mid-March planting. Gradual decrease in germination (\%) of setts was observed with the delay in planting due to prevailing lowest air temperature. It has 
been observed that speed and percent of germination are greatly reduced when ambient temperature goes below $20^{\circ} \mathrm{C}$ and soil moisture stress exists (Miah et al., 2003).

\section{Interaction effects of variety and planting date}

Interaction effect of variety and planting date on germination percentage was significant (Table 2). The maximum germination percentage $(73.67 \%)$ was observed in mid-November planting with the variety Isd 38 but statistically similar in mid-November planting with the variety Isd $39(70.67 \%)$ and the lowest $(51.33 \%)$ was observed in mid-March planting with the variety Isd 39 which was statistically followed by the other treatments.

\section{Tiller production $\left(\times 10^{3} \mathrm{ha}^{-1}\right)$}

\section{Effects of variety}

There was no significant response in tiller production of different varieties (Table 1). However, the variety Isd 38 gave the maximum tiller $\left(94.17 \times 10^{3} \mathrm{ha}^{-1}\right)$ compared to that of the variety Isd 39 (87.58 $\left.\times 10^{3} \mathrm{ha}^{-1}\right)$.

\section{Effects of planting date}

Planting date had a significant effect on tiller production (Table 1). The results revealed that the highest number of tiller $\left(111.03 \times 10^{3} \mathrm{ha}^{-1}\right)$ was observed in mid-November planting and the lowest $(80.48 \times$ $10^{3} \mathrm{ha}^{-1}$ ) from mid-March planting.

Table 1. Germination percentage, tiller production, millable caneand pol\% cane as affected by variety and planting date

\begin{tabular}{lcccc}
\hline \multicolumn{1}{c}{ Treatments } & $\begin{array}{c}\text { Germination } \\
\text { percentage }\end{array}$ & $\begin{array}{c}\text { Tiller production } \\
\left(\times \mathbf{1 0}^{\mathbf{3}} \mathbf{h a}^{-\mathbf{1}}\right)\end{array}$ & $\begin{array}{c}\text { Millable cane } \\
\left(\times \mathbf{1 0}^{\mathbf{3}} \mathbf{h a}^{-\mathbf{1}}\right)\end{array}$ & Pol \%cane \\
\hline Variety: & & & & 78.76 \\
Isd 38 & 59.40 & 94.17 & 74.13 & 13.95 \\
Isd 39 & 57.67 & 87.58 & $\mathrm{NS}$ & 13.71 \\
LSD at 5\% & $\mathrm{NS}$ & $\mathrm{NS}$ & & $\mathrm{NS}$ \\
\hline Planting time: & & & $91.12 \mathrm{a}$ & $14.91 \mathrm{a}$ \\
Mid-November & $72.17 \mathrm{a}$ & $111.03 \mathrm{a}$ & $82.44 \mathrm{~b}$ & $13.97 \mathrm{ab}$ \\
Mid-December & $59.83 \mathrm{~b}$ & $93.56 \mathrm{~b}$ & $79.15 \mathrm{~b}$ & $13.73 \mathrm{~b}$ \\
Mid-January & $54.50 \mathrm{bc}$ & $88.47 \mathrm{bc}$ & $69.75 \mathrm{c}$ & $13.40 \mathrm{~b}$ \\
Mid-February & $53.67 \mathrm{bc}$ & $80.83 \mathrm{c}$ & $59.75 \mathrm{~d}$ & $13.13 \mathrm{~b}$ \\
Mid-March & $52.50 \mathrm{c}$ & $80.48 \mathrm{c}$ & 7.44 & 1.02 \\
\hline LSD $(0.05)$ & 7.02 & 10.51 & 8.02 & 6.06 \\
\hline CV (\%) & 9.89 & 9.54 & & \\
\hline
\end{tabular}

In a column, figures with similar or without letter do not differ significantly and those with dissimilar letter significant at $5 \%$ level. $\mathbf{N S}=$ Not significant

The early planted crops produced higher number of tillers but progressively declined with delayed planting. Number of tiller consequently affects the yield of sugarcane and is therefore considered to be an important parameter of sugarcane crop (Loganandhan et al., 2013). The possible reason for lower tillers in late sowing could be that delay in planting date might result in reducing germination percent due to low temperature which could consequently produce lesser number of tillers. Similar results were obtained by Omoto and Abayo (2005) who also reported that delaying planting date reduces number of tillers.

\section{Interaction effects of variety and planting date}

Interaction effect of variety and planting date on tiller production was significant (Table 2). The maximum tiller production $\left(115.39 \times 10^{3} \mathrm{ha}^{-1}\right)$ was observed in mid-November planting with the variety 
Isd 38 but statistically similar in mid-November planting with the variety Isd $39\left(106.66 \times 10^{3}\right.$ ha $\left.^{-1}\right)$ and the lowest $\left(78.38 \times 10^{3} \mathrm{ha}^{-1}\right)$ was observed in mid-March planting with the variety Isd 39 .

Table 2. Interaction effect of variety and planting date on germination percentage, tiller production, millable cane and pol\% cane

\begin{tabular}{clcccc}
\hline \multicolumn{1}{c}{ Treatments } & $\begin{array}{c}\text { Germination } \\
\text { percentage }\end{array}$ & $\begin{array}{c}\text { Tiller production } \\
\left(\times 10^{3} \mathrm{ha}^{-1}\right)\end{array}$ & $\begin{array}{c}\text { Millable cane } \\
\left(\times 10^{3} \mathrm{ha}^{-1}\right)\end{array}$ & Pol \% cane \\
\hline Isd 38 & Mid-November & $73.67 \mathrm{a}$ & $115.39 \mathrm{a}$ & $98.16 \mathrm{a}$ & $14.95 \mathrm{a}$ \\
& Mid-December & $60.67 \mathrm{~b}$ & $98.70 \mathrm{bc}$ & $84.05 \mathrm{~b}$ & $14.20 \mathrm{abc}$ \\
& Mid-January & $54.67 \mathrm{~b}$ & $94.44 \mathrm{bcd}$ & $80.61 \mathrm{bc}$ & $13.73 \mathrm{abc}$ \\
& Mid-February & $54.33 \mathrm{~b}$ & $82.58 \mathrm{de}$ & $70.33 \mathrm{cde}$ & $13.63 \mathrm{abc}$ \\
& Mid-March & $53.67 \mathrm{~b}$ & $79.72 \mathrm{de}$ & $60.61 \mathrm{ef}$ & $13.33 \mathrm{c}$ \\
\hline Isd 39 & Mid-November & $70.67 \mathrm{a}$ & $106.66 \mathrm{ab}$ & $84.08 \mathrm{~b}$ & $14.87 \mathrm{ab}$ \\
& Mid-December & $59.00 \mathrm{~b}$ & $88.42 \mathrm{cde}$ & $80.83 \mathrm{bc}$ & $13.83 \mathrm{abc}$ \\
& Mid-January & $54.33 \mathrm{~b}$ & $82.50 \mathrm{de}$ & $77.69 \mathrm{bcd}$ & $13.50 \mathrm{bc}$ \\
& Mid-February & $53.00 \mathrm{~b}$ & $81.95 \mathrm{de}$ & $69.16 \mathrm{def}$ & $13.47 \mathrm{bc}$ \\
\hline LSD at 5\% & Mid-March & $51.33 \mathrm{~b}$ & $78.38 \mathrm{e}$ & $58.89 \mathrm{f}$ & $12.77 \mathrm{c}$ \\
CV $(\%)$ & 9.93 & 14.86 & 10.52 & 1.44 \\
\hline
\end{tabular}

In a column, figures with similar or without letter do not differ significantly and those with dissimilar letter significant at $5 \%$ level.

\section{Millable cane $\left(\times 10^{3} \mathrm{ha}^{-1}\right)$ stalks production}

\section{Effects of variety}

Millable cane production was not influenced significantly by varieties (Table 1). Results indicated that the numerically maximum $\left(78.76 \times 10^{3} \mathrm{ha}^{-1}\right)$ millable cane produced from the variety Isd 38 than the variety Isd $39\left(74.13 \times 10^{3} \mathrm{ha}^{-1}\right)$.

\section{Effects of planting date}

Planting date exhibited a significant effect on millable cane production (Table 1). The results stated that the highest millable cane production $\left(91.12 \times 10^{3} \mathrm{ha}^{-1}\right)$ was found in mid-November planting and the lowest $\left(59.75 \times 10^{3} \mathrm{ha}^{-1}\right)$ from mid-March planting. The higher millable cane production in early planting might be due to increased photosynthesis resulted by higher leaf area in early planting and thereby increased higher millable cane production. The results are in lined with those of Ferdous et al. (2015) which also stated that higher millable cane production was significantly higher in early planting. Munsif et al. (2018) also observed that higher millable cane production was achieved from early planting.

\section{Interaction effects of variety and planting date}

A significant effect of millable cane production was observed due to interaction between variety and planting date (Table 2). Mid November planting with the variety Isd 38 produced the highest millable cane $\left(98.16 \times 10^{3} \mathrm{ha}^{-1}\right)$ and the lowest $\left(58.89 \times 10^{3} \mathrm{ha}^{-1}\right)$ was observed from mid-March planting with the variety Isd 39.

\section{Pol \% cane}




\section{Effects of variety}

Pol $(\%)$ cane was not significantly response by varieties (Table 1$)$. The variety Isd 38 produced the maximum (13.95\%) pol (\%) cane than Isd $39(13.71 \%)$.

\section{Effects of planting date}

Planting date had a significant effect on pol (\%) cane (Table 1). The results indicated that the maximum pol $(\%)$ cane $(14.91 \%)$ was measured from mid-November planting but statistically similar with midDecember planting (13.97\%) whereas, the lowest pol (\%) cane (13.13\%) from mid-March planting.Sanghera et al. (2016)reported that planting from 15th October to 30th October resulted in low pol (\%) cane while 15 November planting showed promising results for enhancement of pol (\%) cane. Abbas and Hossan (2015)observed that pol decreased from $12 \%$ to $6.71 \%$ by delay in planting. Almodares and Darany (2006) also stated that higher pol (\%) cane was recorded in early plantings. Similar trend was reported by Hoque et al. (1994) in Bangladesh condition.

\section{Interaction effects of variety and planting date}

Interaction between variety and planting date on pol (\%) cane was significant (Table 2). The highest pol $(\%)$ cane $(14.95 \%)$ was observed in mid-November planting with the variety Isd 38 but statistically similar in mid-November planting with the variety Isd $39(14.87 \%)$ and the lowest $(12.77 \%)$ in midMarch planting with the variety Isd 39 which was statistically followed by the other treatments.

\section{Cane yield}

\section{Effects of variety}

The results revealed that sugarcane yield was significantly influenced by variety at harvest (Figure 1). Between the varieties, higher yield $\left(75.47 \mathrm{t} \mathrm{ha}^{-1}\right)$ was obtained from variety Isd 38 than the variety Isd $39\left(67.84 \mathrm{t} \mathrm{ha}^{-1}\right)$. Yield is the contribution of several attributes like number of millable stalk, stalk length and girth of cane. Getaneh et al. (2016) observed that significant response represents among different varieties. Khan et al. (2003) reported that increase in cane yield might be due to maximum plant height, weight per stool and cane girth. Variation among sugarcane varieties in respect of cane yield has also been reported by Jamil et al. (2007).

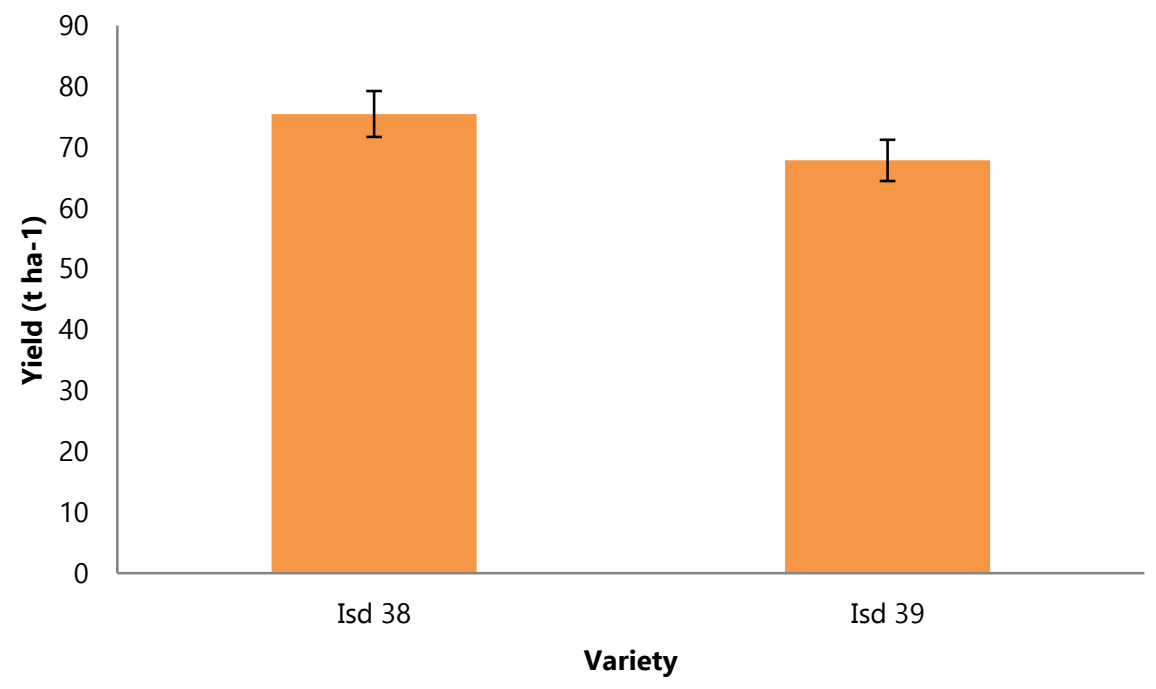

Fig. 1.Sugarcane yield as influenced by variety 


\section{Effects of planting date}

Planting date performed significant variation on sugarcane yield at harvest (Figure 2). The results indicate that the maximum yield $\left(87.96 \mathrm{t} \mathrm{ha}^{-1}\right)$ was found in mid-November planting, whereas, the lowest yield (51.94 $\left.\mathrm{t} \mathrm{ha}^{-1}\right)$ was obtained from mid-March planting.

The possible reason for this reduction with delay planting might be due to the reduction in number of tiller, stem diameter, internode length and plant height. The results are in lined with that of Jintrawet $e t$ al. (2000)who investigated that early planted sugarcane gave higher cane yield. Early planting resulted in higher yield of $19.87 \%$ as compared to late planting. This result support the findings of Hoque et al. (1994) where they reported significant reduction in cane yields from planting beyond November. Similar results were observed by Hoy et al.(2006).

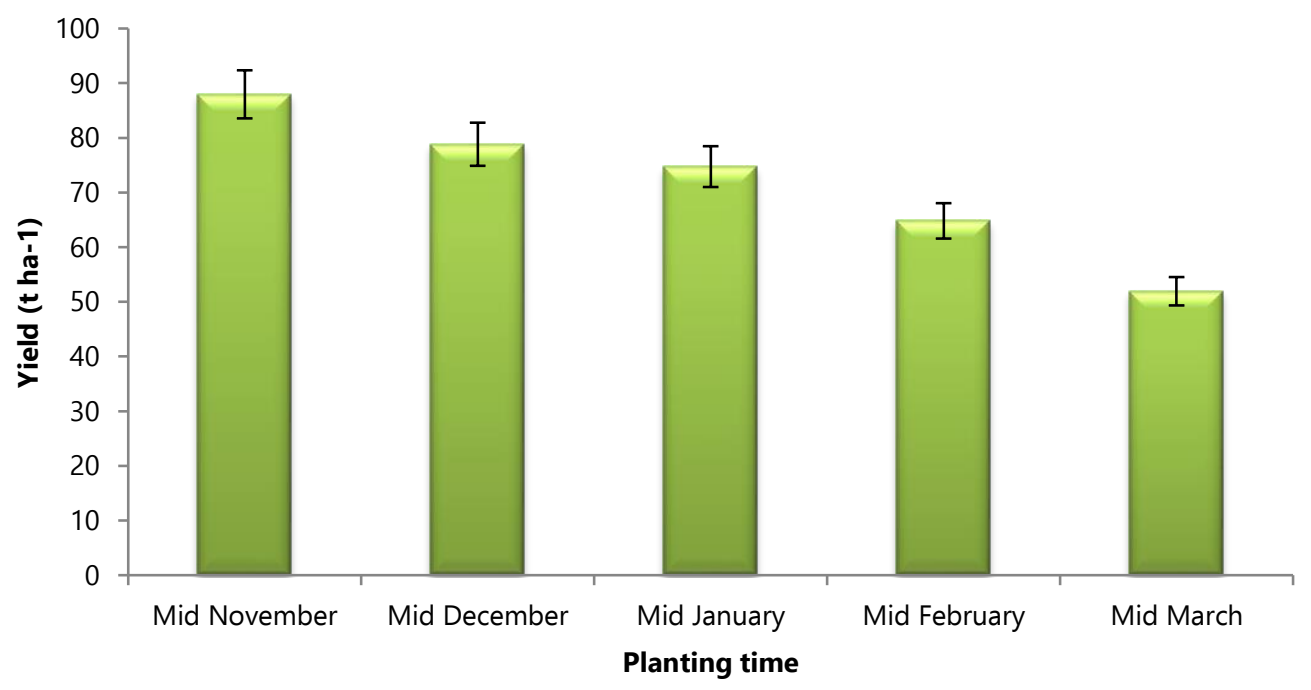

Fig. 2.Sugarcane yield as influenced by planting date

\section{Interaction effects of variety and planting date}

A significant response observed in sugarcane yield among the interaction between variety and planting date at harvest (Figure 3). Results indicated that the highest yield $\left(93.64 \mathrm{t} \mathrm{ha}^{-1}\right)$ was obtained from midNovember planting with the variety Isd 38 whereas, the lowest yield $\left(40.66 \mathrm{t} \mathrm{ha}^{-1}\right)$ was observed in mid-March planting with the variety Isd 39. 


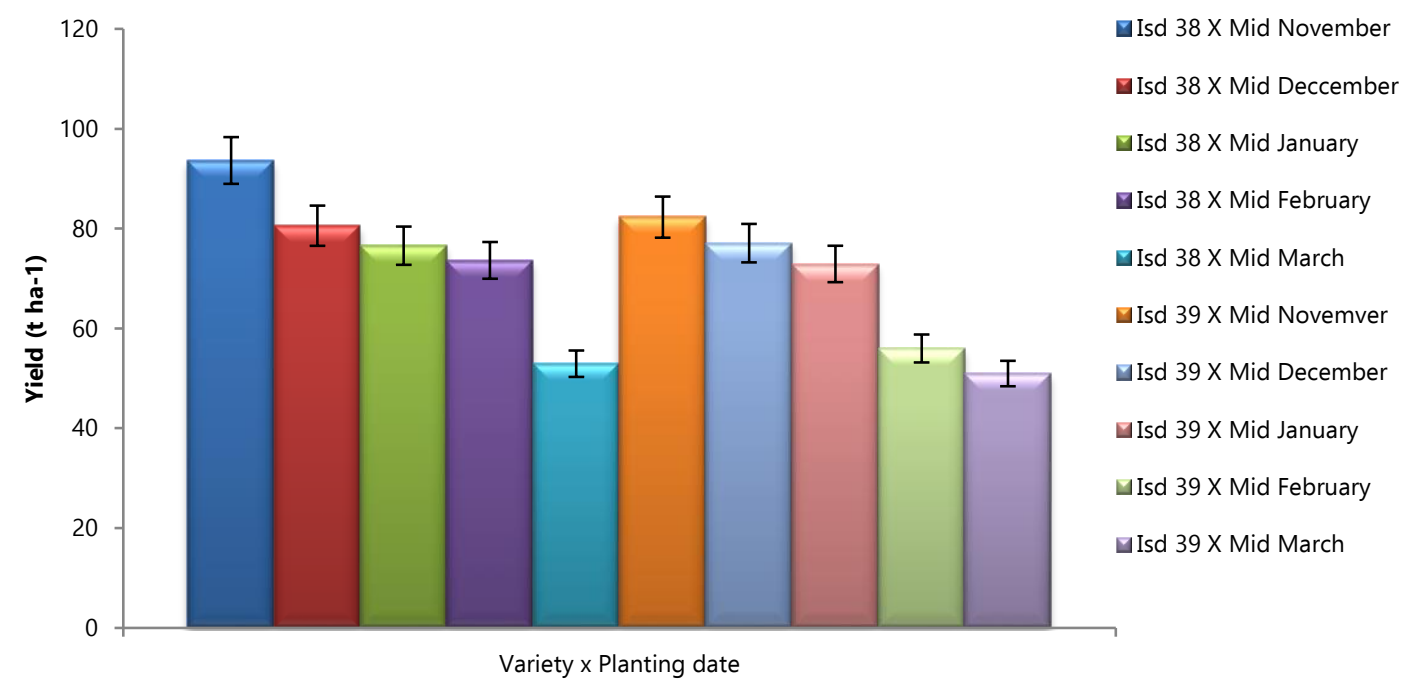

Fig. 3. Sugarcane yield as influenced by interaction effect of variety and planting date

\section{Conclusion}

The results indicated that sugarcane variety Isd 38 when planting inmid-November resulted in higher cane yield while delayed planting decreased cane yield. Thus, variety Isd 38 with planting of setts in the month of mid-November is recommended for obtaining higher yield of Sugarcane under the Modhupur tract soils in Bangladesh.

\section{References}

Abbas, A. and S. Hossan. 2015. Effect of sowing dates and nitrogen levels for ethanol production from sweet sorghum stalks and grains. Afr. J. Agric. Res. 11 (4): 266-275.

Almodares, A. and S.M.M. Darany. 2006. Effects of planting date and time of nitrogen application on yield and sugar content of sweet sorghum. J. Environ. Biol. 27: 601-605.

Alam, M.M., G.M.M. Alam, M.A.S. Miah and S. M. K. Rahman. 2009. Factors affecting sugar recovery of Bangladesh sugar industry. Pakistan Sugar J. 24(1): 14-20.

Azam, M. and M. Khan. 2010. Significance of the sugarcane crops with special reference to Khyber Pakhtunkhwa. Sarhad. J. Agric. 26(2): 289-295.

BARC (Bangladesh Agricultural Research Council). 2005. Fertilizer Recommendation Guide. Published by BARC, New Airport Road, Farmgate, Dhaka-1215. pp. 97-136.

BBS 2019. Statistical Yearbook of Bangladesh. Bangladesh Bureau of Statistics. Planning Division, Ministry of Planning. Government of the Peoples' Republic of Bangladesh. p. 167.

Chattha, A.A., M. Rafique, M. Afzal, F. Ahmed and M. Bilal. 2006. Prospects of sugar industry \& sugarcane cultivation in Punjab. Proceedings of 41th Annual Convention of Pakistan Society of Sugar Technologists held at Rawalpindi on August 21-22, 2006. pp. 173-181.

Chattha, M.U. and E. Ehsanullah. 2003. Ehsanullah Agro-quantitative and qualitative performance of different cultivars and strains of sugarcane (Saccharum officinarum L.). Pakistan Sugar J. 18(06):25.

Ferdous, H.M., Q.A. Khaliq and A. Karim. 2015. Effect of sowing dates on growth and yield of tropical sugarbeet. Int. J. Agron. Agric. Res., 1 (7): 53-60. 
Getaneh, A., F. Tadesse, N. Ayele and M. Bikilla. 2016. Agronomic performance evaluation of sugarcane varieties under Finchaa Sugar Estate agro-ecological conditions. Afr. J. Agric. Res. 11(44: 44254433.

Hoque, M.A.,M.M. Uddin and M.N.U. Khan. 1994. Effect of time and methods of planting on yield and quality of sugarcane. Bangladesh J. Sugarcane. 16: 146-151.

Hossain, M. S., M.A.T. Sohel, A.K.M.R. Islam, M.J. Alam and M.K. Rahman. 2011. Effect of planting date on growth, yield and juice quality of sugarcane. The Planter, Kuala Lumpur, 87 (1028): 200-206.

Hoy, J.W., A.E. Arceneaux and C.F. Savario. 2006. Effect of date and rate of billetplanting on sugarcane yield. J. Am. Soc. Sugarcane Tech. 26(1): 116-124.

Jintrawet, A., S. Laohasiriwong and C. Lairuengroeng. 2000. Predicting the effect of planting dates on sugarcane performance in Thailand. P. 28-29. Proceedings of International CANEGRO Workshop. August, 4-7.

Jamil, M., S. Afghan, M.A. Majid and A. Rasool. 2007. Ratooning performance of different sugarcane varieties. Pakistan Sugar J. 22(3):38-47.

James, G. 2004. Sugarcane (2nd ed.). Blackwell Science Ltd, UK pp. 109-125.

Kabir, M.L. 1998. Effect of planting time and techniques on the yield and yield contributing parameters of sugarcane. M. S. Thesis. Department of Agronomy. Bangladesh Agricultural University. Mymensingh. pp. 21-30.

Khan, M.A., H.K. Keerio, S. Junejo, R.N. Panhwar, M.A. Rajput, Y.M. Memon and B.R. Qazi. 2003. Evaluation of new sugarcane genotypes developed through fuzz. Correlation of cane yield and yield components. Pakistan J. Applied Sci. 3(4): 270-273.

Loganandhan, N., Gujja, Biksham, Goud, Vinod and U.S. Natarajan. 2013. Sustainable sugarcane initiative (SSI): A methodology of more with less. Sugar Technol. 15(1): 98-102. https://doi.org/10.1007/s12355-012-0180-y

Miah, M.A.S.,M.A.Hossain, M.F. Hasan, S.Aliand M.R.Alam. 2003. Sugarcane germination under subtropical climate in Bangladesh. Indian Sugar. 52(12): 991-1001.

Mian, A.M. 2006. Sugarcane variety composition in Pakistan. Proceedings of Seminars on Agriculture. Organized by Pakistan Society of Sugar Technologists held at Faisalabad on $19^{\text {th }}$ June 2006. pp.107-121.

Mohamed, B.D. and A.B.A. El-Taib. 2007. Evaluation of some spring planted sugarcane genotypes under different growing seasons: 1-Quality traits performance. Assiut. J. Agric. Sci. 38(1):1-15.

Munsif, F., M. Zahid, M.Arif, K. Ali and I. Ahmad. 2018. Influence of planting date on yield and quality of sugarcane under the agro-climatic conditions of Mardan. Sarhad J. Agric. 34(3): 649-655.

Nazir, A., G.A. Jariko and M.A. Junejo. 2013. Factors affecting sugarcane production. Pak. J. Commer. Soc. Sci. 7(1): 128-140.

Omoto, G. and G.O. Abayo. 2005. Effect of delayed planting of seed cane on sugarcane germination, growth rate and yield. Kenya Sugar Research Foundation, Technical Bulletin No. 2 (May, 2005).

Rahman, M.S.,S. Khatun and M.K. Rahman. 2016. Sugarcane and Sugar Industry in Bangladesh: An Overview. Sugar Tech. 18 (6). 10.1007/s12355-016-0489-z.

Soomro, A.F., S. Tunio, F.C. Oad and I. Rajper. 2013. Integrated effect of inorganic and organic fertilizer on yield and quality of sugarcane. Pak. J. Bot. 45(4): 1339-3148.

Shukla, S.K. and I. Singh. 2011. Tillering pattern, growth and yield of three promising genotypes of sugarcane under three fertility levels in sub-tropical India. India. J. Sugarcane Tech. 26(2): 10-13.

Sanghera, G.S., R. Kumar, V. Tyagi, K.S. Thind and B. Sharma. 2016. Genetic divergence among elite sugarcane clones (Saccharum officinarum L.) based on cane yield and quality traits from northern India. J. Exp. Biol. Agric. Sci., 3(2): 184-190.

Sundara, B. 2000. Sugarcane Cultivation. Vicas Publishing House Pvt. Ltd., New Delhi, India. 
Viator, R.P., E.P. Richard Jr., D.D. Garrison, E.O. Dufrene Jr. and T.L. Tew. 2005. Sugarcane cultivar yield response to planting date. J. Amer. Soc. Sugarcane Technol. 25: 78-87.

Worku, B. and S. Chinawong. 2006. Agronomic Performances and Industrial Characterstics of Sugarcane Varieties Under Finchaa Valley Conditions, Oromiya, East Africa. Kamphaengsaen Acad. J. 4(1): 27-33. 